\title{
Endometrial biopsy with uretral plastic No. 12 sonde
}

\author{
Cancer Preventive Service, Gynecological Oncology Department, \\ Instituto de Câncer Antonio Vieira de Carvalho, Escola Paulista de Medicina - São Paulo, Brazil
}

\begin{abstract}
The authors demonstrate technique for obtaining endometrial fragments in 25 patients sent to Gynecological Cancer Preventive Service of the Arnaldo Vieira de Carvalho Cancer Institute, during the period of September 1991 through January 1992 , presenting abnormal uterine hemorrhage.

Technique consists in vacuum aspiration with the support of a No. 12 uretral sonde, provided with one lateral opening only. Correlation with curettage was positive in $88 \%$ of the patients; biopsy with sonde did not result in confirmation in three patients only. No complications at all were observed (infection, hemorrhage or uterus perforation).

Authors understand that this method is in conformity with a correct diagnostic performance, being a low cost procedure, almost painless, easy to be done and furnishing sufficient material for the histo-pathologic diagnosis, in $88 \%$ of the cases studied.
\end{abstract}

UNITERMS: Endometrial biopsy. Abnormal uterine hemorrhage.

\section{INTRODUCTION}

$\mathrm{U}$ terine curettage, today, still continues being a very important resource for assessment of women inclined to an uterine cancer and diagnosis of abnormal hemorrhage (KAUNITZ et al., 1988).

Address for correspondence:

Fausto Farah Baracat

Av. Angélica, $916-7^{\circ}-$ cj. 707

São Paulo - SP - Brasil - CEP 01228-000
However, confinement and anesthesia needs make this procedure not feasible to be done at ambulatory premises. As a result, other countless methods have been tried, such as the Vabra aspirator, rotating of a small brush in the endometrial cavity (De BRUX) and the Novak curette.

From these, the method that more approaches nearly to an uterine curettage is, without any doubt, the Vabra aspirator, resulting in a correlation of $96 \%$ (JENSEN, 1970; GRIMES, 1982), however, the need of a vacuum electrically obtained, makes this method expensive and difficult to perform (SLEDMERE, 1981; BUTLER, 1984).

So, we proposed ourselves to test, here, a low cost and easily applicable technique, consisting in the aspiration of endometrial fragments through an uretral sonde attached to a $20 \mathrm{ml}$ syringe and compare the results obtained with the uterine curettage already made in these same patients. 
Twenty-five patients, sent by the Gynecological Cancer Preventive Service of the ICAVC, were included in the study, during the period of September 1991 through January 1992, presenting abnormal uterine hemorrhage.

Age of patients varied from 40 to 74 years, resulting in an average of 52.4. First of all, an accurate gynecological examination is done: valva, vagina and uterine coli are examined with a colposcope, in order to exclude other causes, besides the abnormal endometrial cavity bleeding.

After vaginal embrocation with lugol, a No. 12 sonde is introduced in the uterine cavity, by the support of a Cheron pinnace; in $90 \%$ of the cases seizure or enlargement of the uterine coli was not necessary, as the sonde surpassed easily the resistance of both, the external and internal cervical ostiums.

Once placed in the uterine coli, sonde is fixed to the syringe-grasp set and, with the help of one of the hands, vacuum is crated. Right after, without destroying the vacuum, with the other hand, sonde is brought out of the endometrial cavity. This procedure must be repeated 3 times, approximately, in order to get material necessary for the histopathologic examination. After these aspirations are performed, endometrial fragments are observed in the interior of the sonde, mixed to mucus and blood.

Material of the sonde is taken off by passing a $10 \%$ formol solution with the aid of a syringe.

A very important detail to be observed when the sonde is made out in plastic material is that it "must have only one lateral opening", as models presenting two or more openings loss vacuum easily, being not possible an adequate collection of material.
Patients were submitted to curettage proofs days after biopsy by sonde was made and results were compared.

\section{RESULTS}

Results showed a $88 \%$ positive correlation between biopsy and curettage proofs; biopsy with sonde could not collect material of seven patients.

In four of them, the pathologic anatomy examination of the curettage material was harmonious and, in other three patients, endometrial was of atrophic type.

There were two endometrial G1 and G2 adenocarcinoma cases; two adenomatosis hyperplasia without any atypias and one of cystic hyperplasia.

Seven cases of secretory endometrial, four of proliferative endometrial and two others where aspiration got endocervical glands only (Table 1).

No complications at all were observed considering both of the methods (hemorrhage, infection or perforation). Most of the patients showed a good tolerance to sonde biopsy, being the uterine coli seizure needed in only $20 \%$ of the cases.

\section{DISCUSSION}

Several methods for obtaining endometrial material have been utilized; these techniques involve suction, irrigation followed by aspiration (Grav-Lee), rotation of a

Table 1

Results of biopsy with sonde compared to the obtained in curettage proof

\begin{tabular}{lll}
\hline Nr.of cases & Biopsy with sonde & Curettage proof \\
\hline 02 & Endometrial adenocarcinoma & Endometrial adenocarcinoma \\
02 & Adenomatosis hiperplasia & Adenomatosis hiperplasia \\
01 & Without atypias & Without atypias \\
07 & Cystid hiperplasia & Cystid hiperplasia \\
04 & Endometrial secretory & Endometrial secretory \\
04 & Mucus and fibrine & Mucus and fibrine \\
02 & Endocervical gluds & Mucus and fibrine \\
03 & Mucus and fibrine & Atrophic endometrial \\
\hline
\end{tabular}


small brush in the endometrial cavity (De Brux brush), Novak curette and, more recently, a new device for aspirative biopsy obtainance, named "endometrial pipelle" (KAUNITZ et al., 1988).

These methods have shown very accurate diagnostics varying from $70 \%$ to $92 \%$ (GUSBERG et al., 1981; BIBBO et al., 1982; KOSS et al., 1982), with the disadvantage that, cytological techniques (brushing, irrigation, etc.), need professional trained in this area (KOSS et al., 1981; KOSS et al., 1982; POISON et al., 1984; FERENCZY et al., 1984) as, even the most experients face difficulties in the correct diagnosis (KAUNITZ et al., 1988).

Until hystereoscopy does not become a widely diffused procedure in our area, curettage continues being as the standard method for the endometrial cavity study. The more similar procedure is the Vabra aspirator, presenting a correlation of $96 \%$ with the uterine curettage (JENSEN, 1970; GRIMES, 1982). This procedure, however, needs vacuum electrically obtained, making this method more expensive and difficult to be applied (SLEDMERE, 1981; BUTLER, 1984).

\section{CONCLUSION}

It is an easy method, can be ambulatorily performed, almost painless, presenting a minimum risk and at low cost, presenting quite satisfactory results $(88 \%)$ and, consequently, indicated adequately for diagnosis purpose in what refers to endometrial injuries.

Feasibility justifies propaedeutics.

\section{Resumo}

Introdução: Os autores demonstram a técnica de obtenção de fragmentos endometriais em 25 pacientes encaminhadas ao Serviço de Prevenção do Câncer Ginecológico do Instituto do CâncerArnaldo Vieira de Carvalho por quadro de sangramento uterino anormal no período de setembro de 1991 a janeiro de 1992.

Material e Métodos: A técnica consistiu na vácuo aspiração do endométrio com auxílio de sonda uretral n²12 de orifício lateral único.

Resultados: A correlação com curetagem foi positiva em $88 \%$ dos casos; a biópsia com sonda não mostrou confirmação em apenas três pacientes. Não foram observadas complicações de qualquer espécie (infecção, hemorragia ou perfuração uterina).

Conclusão: Os autores concluem que o método está adequado a uma correta abordagem diagnóstica, trata-se de procedimento de baixo custo, pouco doloroso, de fácil execução e que possibilitou material suficiente para o diagnóstico histopatológico em $88 \%$ dos casos estudados.

\section{REFERENCES}

1. BIBBO, M.; KLUSKENS, L. \& AZIZI, F. - Accuracy of three sampling techniques for the diagnoses of endometrial cancer and hyperplasia. J Reprod Med 27:622, 1982.

2. BUTLER, E.B. - The Pipelle: A disposable device for endometrial biopsy. Am J Obstet Gynecol 148:109, 1984.

3. FERENCZY, A. \& GELFAND, M.M. - Out patient endometrial sampling with the endometrial sampling with the endocyte: Comparative study of its effectiveness with endometrial biopsy. Obstet Gynecol 63:295, 1984.

4. GRIMES, D.A. - Diagnostic dilation and curettage: A reappraisal. Am J Obstet Gynecol 142:1, 1982.

5. GUSBERG, S.B. \& MILANO, C. - Detection of endometrial cancer and its precursors. Cancer 47:1173, 1981.

6. JENSEN, J.G. - Vacuum curettage: outpatient curettage without anesthesia: A report of 350 cases. Dan med Bull 17:199, 1970.
7. KAUNITZ, A.M.; MASCIELO, A.; OSTROVISKI, M. \& ROVIRA, E.Z. - Comparison of endometrial biopsy with the endometrial pipelle and valvra aspirator. J Reprod Med 33:427-31, 1988.

8. KOSS, L.A.; SCHREIBER, K. \& MOUSSOURES, H. Endometrial carcinoma and its precursor: detection and screening. Clin Obstet Gynecol 25:49, 1982.

9. KOSS, L.G.; SCHREIBER, K. \& OBERLANDER, G.G. Screening of asymptomatic women for endometrial cancer. Obstet Gynecol 57:681, 1981.

10. POISON, D.W.; MORSE, A. \& BEARD, R.W. - An alternative to diagnostic dilation and curettage: endometrial cytology. Br Med J 288:981, 1984.

11. SLEDMERE, C.M.; READING, A.E. \& YOUNG, O. Psychological aspects of vabra curettage in menopause clinics. Maturitas 3:205, 1981. 